\title{
Kepekaan Erythricium salmonicolor Penyebab Penyakit Jamur Upas pada Kemiri Sunan terhadap Suhu, Cahaya, dan Fungisida
}

\author{
Sensitivity of Erythricium salmonicolor, the Pink Disease Causal \\ Agent of Reutealis trisperma, to Temperature, Light, and Fungicides
}

\author{
Dini Florina ${ }^{1 *}$, Dono Wahyuno ${ }^{1}$, Siswanto ${ }^{2}$ \\ ${ }^{1}$ Balai Penelitian Tanaman Rempah dan Obat, Bogor 16111 \\ ${ }^{2}$ Pusat Penelitian dan Pengembangan Perkebunan, Bogor 16111
}

\begin{abstract}
ABSTRAK
Gejala khas penyakit jamur upas ditemukan pada tanaman kemiri sunan (Reutealis trisperma) di Bogor. Penelitian ini bertujuan menentukan cendawan penyebab dan kepekaannya terhadap suhu, cahaya, dan fungisida. Cendawan diidentifikasi berdasarkan karakter morfologi. Inokulum diperoleh dari isolasi jaringan kulit batang terinfeksi. Uji patogenisitas dilakukan dengan menempelkan potongan cabang kemiri sunan yang sudah terkolonisasi pada bibit kemiri sunan dan diinkubasi di rumah kaca. Pengaruh suhu terhadap cendawan dilakukan dengan menanam koloni cendawan uji pada medium agaragar dekstrosa kentang (ADK) dan diinkubasi pada suhu $25-34{ }^{\circ} \mathrm{C}$. Kepekaan cendawan pada cahaya diuji dengan menanam koloni cendawan di dalam labu berisi medium kaldu dekstrosa kentang (KDK) pada shaker (60 rpm) yang terpapar cahaya (400 luks) atau pada kondisi gelap selama 15 hari pada suhu $25{ }^{\circ} \mathrm{C}$. Bobot segar dan kering miselium cendawan yang diperoleh ditimbang. Efikasi tembaga hidroksida dan mankozeb diuji dengan menanam cendawan uji dimedium ADK yang diteteskan fungisida uji dengan konsentrasi 100, 200, 300, 400 dan 500 ppm. Cendawan penyebab jamur upas pada kemiri sunan diidentifikasi sebagai Erythricium salmonicolor berdasarkan karakteristik morfologinya. Pada uji patogenisitas, miselium E. salmonicolor tumbuh dan membentuk jaring laba-laba pada bibit 3 minggu setelah inokulasi. Cendawan uji dapat tumbuh pada semua kisaran suhu yang diuji, tetapi suhu optimum pertumbuhan $E$. salmonicolor adalah $28^{\circ} \mathrm{C}$. Cahaya tidak berpengaruh nyata terhadap pertumbuhan $E$. salmonicolor. Mankozeb menekan pertumbuhan koloni E. salmonicolor lebih baik dibanding tembaga hidroksida.
\end{abstract}

Kata kunci: identifikasi morfologi, mankozeb, tembaga hidroksida, uji patogenisitas

\section{ABSTRACT}

A typical pink disease symptom appeared on stem of Reutealis trisperma in Bogor. The present study was aimed for confirming the causal pathogen and testing its sensitivity to temperature, light and fungicides. The fungus was identified based on its morphological characteristics. The fungal inoculum was obtained by tissue isolation of infected stem bark. For pathogenicity test, the fungus was inoculated onto sterilized pieces of woody $R$. trisperma branch, then fastened on the seedlings and incubated in the green house. The effect of temperatures on fungal growth was tested by planting the fungal colony onto potato dextrose agar (PDA) then incubated at $25-34{ }^{\circ} \mathrm{C}$. The sensitivity of the fungus to light was tested by inoculating the fungus into flask with potato dextrose broth (PDB) medium on a shaker (60 $\mathrm{rpm}$ ) exposing it to white light tube (400 luks) or in a dark condition for 15 days at $25{ }^{\circ} \mathrm{C}$. The obtained

*Alamat penulis korespondensi: Balai Penelitian Tanaman Rempah dan Obat.

Jalan Tentara Pelajar No. 3. Bogor 16111

Tel: 0251-8321879, Faks: 0251-8327010, Surel: dindinrina@gmail.com 
fungal colonies were weighed. Efficacy of copper hydroxide and mancozeb against the fungal colony growth was tested by inoculating the fungus onto PDA amended with 100, 200, 300, 400, and 500 ppm, respectively, of tested fungicides. The results showed that the causal pathogen was Erythricium salmonicolor. In the pathogenicity test, cobwebs of E. salmonicolor were formed on inoculated seedlings 3 weeks after inoculation. The optimum temperature for growth of E. salmonicolor was $28{ }^{\circ} \mathrm{C}$. There was no significant effect of light on fungal growth. Mancozeb suppressed colony of $E$. salmonicolor growth better than copper hydroxide.

Keywords: morphological identification, mancozeb, copper hydroxide, pathogenicity test

\section{PENDAHULUAN}

Kemiri sunan (Reutealis trisperma; syn. Aleurites trisperma) merupakan tanaman asli Filipina yang telah beradaptasi luas di Indonesia (Aguilar dan Oyen 2002) dan mampu menghasilkan minyak nabati yang dapat diproses untuk sumber energi terbarukan. Koleksi tanaman kemiri sunan di petak koleksi Pusat Penelitian dan Pengembangan Perkebunan Cimanggu, Bogor menunjukkan gejala terserang jamur upas (pink disease) (Gambar 1a) yang dicirikan adanya tepi koloni cendawan berwarna putih terang. Koloni cendawan patogen yang menyerang batang utama (Gambar 1b) dan cabang (Gambar 1c) tanaman kemiri sunan terlihat tebal dan berwarna putih. Di Afrika Selatan jamur upas yang disebabkan oleh cendawan Erythricium salmonicolor (syn. Corticium salmonicolor) menjadi penyakit utama karena memiliki inang yang luas (Roux dan Coutzee 2005). Pada tanaman kemiri sunan, penyakit jamur upas belum pernah dilaporkan. Penelitian ini bertujuan memastikan patogen penyebab penyakit jamur upas pada tanaman kemiri sunan serta menentukan apakah suhu,cahaya, dan fungisida berpengaruh terhadap pertumbuhannya.

\section{BAHAN DAN METODE}

\section{Insidensi, Isolasi, dan Identifikasi Patogen}

Pengamatan penyakit tanaman dilakukan di kebun koleksi Pusat Penelitian dan Pengembangan Perkebunan di Bogor dari bulan Maret sampai Agustus 2016. Populasi tanaman yang diamati berjumlah 18 tanaman berumur \pm 5 tahun, jarak tanam $6 \mathrm{~m} \times 6 \mathrm{~m}$.
Insidensi penyakit (IP) dan keparahan penyakit (KP) diukur menggunakan rumus:

$$
\mathrm{IP}=\frac{\mathrm{n}}{\mathrm{N}} \times 100 \% \text {, dengan }
$$

$\mathrm{n}$, jumlah tanaman yang terserang; dan $\mathrm{N}$, jumlah tanaman yang diamati.

$$
\mathrm{KP}=\frac{\sum_{i=0}^{i}\left(\mathrm{n}_{i} \times \mathrm{v}_{i}\right)}{\mathrm{N} \times \mathrm{V}^{*}} 100 \% \text {, dengan }
$$

$n_{i,}$ jumlah tanaman dengan skor ke-i; $v_{i}$, nilai skor penyakit dari $\mathrm{I}=0,1,2$ sampai i t-skor tertinggi; N, jumlah tanaman yang diamati; dan V, skor tertinggi.

Kategori kerusakan menggunakan kriteria Griffin et al. (2003), yaitu: 0, tanaman sehat; 1, koloni pada cabang primer, kanopi masih $75 \%$; 2 , koloni pada batang utama, terdapat retakan pada kulit, kanopi 25-75\%; 3, koloni pada batang utama dan cabang primer, meranting, kanopi $25 \%$; dan 4, tanaman mati.

Isolasi patogen dilakukan dengan merendam potongan kulit pohon terinfeksi ke dalam alkohol 70\% selama 2-3 menit, dibilas dengan air steril dan dikeringanginkan (Akrofi et al. 2014), kemudian diinokulasikan pada medium agar-agar dekstrosa kentang (ADK) dan diinkubasikan pada suhu $25-27^{\circ} \mathrm{C}$ selama 15 hari. Koloni berwarna putih sampai oranye dimurnikan pada medium ADK dan diberi kode EK-01. Ada tidaknya spora seksual dan atau aseksual diamati secara mikroskopi. Selain itu, morfologi cendawan juga diamati dari miselium yang diambil dari permukaan kulit batang tanaman terinfeksi dan membuat preparat menggunakan asam laktat yang diberi pewarna biru kapas sebagai mounting (Gambar 1d). Karakter morfologi (seksual dan aseksual) cendawan patogen EK-01 yang tumbuh di permukaan kulit batang kemiri 
sunan dan miselium yang diambil dari biakan ADK didentifikasi berdasarkan kriteria Jülich (1975).

Cendawan EK-01 ditumbuhkan pada medium ADK berisi potongan ranting kemiri sunan steril $( \pm 5 \mathrm{~cm}$ panjang; berdiameter $\pm 1 \mathrm{~cm}$ ), diinkubasikan pada suhu $28{ }^{\circ} \mathrm{C}$ selama 3 minggu. Potongan ranting yang sudah terkolonisasi ditempelkan pada batang bibit kemiri sunan berumur \pm 1 tahun dengan jarak $\pm 10 \mathrm{~cm}$ dari permukaan tanah (Akrofi et al. 2014). Perlakuan diulang sebanyak 3 kali, masing-masing terdiri atas 3 tanaman. Sebagai kontrol digunakan potongan ranting yang tidak diinokulasi cendawan uji sehingga total tanaman yang digunakan adalah 12 tanaman.

\section{Pengujian Suhu, Cahaya, dan Fungisida}

Pengujian pengaruh suhu dilakukan dengan menumbuhkan cendawan EK-01 pada medium ADK selama 5 hari pada suhu kamar (25-29 $\left.{ }^{\circ} \mathrm{C}\right)$. Bagian tepi koloni cendawan diambil ( $\pm 5 \mathrm{~mm}$ ), ditanam pada medium ADK di cawan petri, kemudian diinkubasi pada suhu $25,28,31$, dan $34{ }^{\circ} \mathrm{C}$ serta diulang 5 kali. Peubah yang diamati ialah pertumbuhan koloni dengan mengukur diameter koloni secara tegak lurus untuk setiap cawan petri kemudian dirata-ratakan.

Pengaruh cahaya terhadap kecepatan tumbuh koloni diuji dengan meletakkan cawan petri yang berisi koloni EK-01 di bawah lampu ( \pm 400 luks) atau diletakkan pada tempat gelap untuk perlakuan tanpa pencahayaan pada suhu inkubasi $28{ }^{\circ} \mathrm{C}$. Setiap perlakuan diulang 5 kali. Peubah yang diamati ialah diameter koloni seperti pada uji suhu. Pengaruh cahaya terhadap bobot koloni dilakukan dalam labu dengan medium kaldu dekstrosa kentang (KDK) dengan kecepatan kocok $60 \mathrm{rpm}$. Koloni cendawan dipanen pada hari ke-15, disaring, dikeringkan dan ditimbang.

Pengujian fungisida berbahan aktif tembaga hidroksida dan mankozeb dilakukan dengan metode peracunan makan (Valarmathi et al. 2013), yaitu menumbuhkan potongan koloni cendawan uji (diameter $\pm 5 \mathrm{~mm}$ ) pada medium ADK di cawan petri yang sudah ditetesi fungisida terlebih dahulu, kemudian diinkubasi pada suhu $28{ }^{\circ} \mathrm{C}$. Konsentrasi bahan aktif fungisida ialah 0 (kontrol), 100, 200, 300, 400 dan 500 ppm. Setiap perlakuan diulang 4 kali dan peubah yang diamati ialah diameter koloni.

\section{HASIL}

\section{Pengamatan lapangan}

Insidensi penyakit tanaman kemiri sunan terinfeksi jamur upas pada awal bulan Maret ialah $27.7 \%$ dan nilainya stabil hingga pengamatan pada bulan Agustus 2016. Tingkat kerusakannya bervariasi mulai skala 0 sampai 3 . Keparahan penyakit pada bulan Maret 2016 ialah $9.72 \%$ dan berkembang hingga $18.06 \%$ pada bulan Agustus 2016. Kondisi kanopi sudah saling bersentuhan dan rapat. Tanaman kemiri sunan yang termasuk kedalam skala 3 daunnya menguning, rontok dan meranggas.

Pada himenium (Gambar 1e) yang diambil dari permukaan kulit batang terinfeksi ditemukan basidium berbentuk gada, hialin dengan 4 sterigma di atasnya. Basidiospora berbentuk bulat sampai lonjong dengan apiculus di ujungnya dan jernih (Gambar 1f dan 1g). Pada koloni yang tebal dan tua, ditemukan konidium yang terbentuk dari fragmentasi hifa (Gambar 1h).

Koloni yang tumbuh pada medium ADK berwarna putih tipis di bagian tepi, di bagian tengah tebal berwarna putih-oranye terang (Gambar 1i). Diameter koloni mencapai 73-77 $\mathrm{mm}$ setelah diinkubasi selama 5 hari pada $28^{\circ} \mathrm{C}$.

Pada uji patogenisitas, miselium cendawan dari subtrat kayu tumbuh di permukaan batang bibit kemiri sunan berwarna putih tebal hingga oranye setelah diinkubasi selama 3 minggu (Gambar 1j).

Berdasarkan karakteristik warna koloni, miselium yang membentuk jalinan himenium, basidium yang berbentuk gada, dan basidiospora yang berbentuk bulat sampai lonjong dengan apiculus di ujungnya, patogen penyebab penyakit jamur upas diidentifikasi sebagai cendawan Erythricium salmonicolor. 


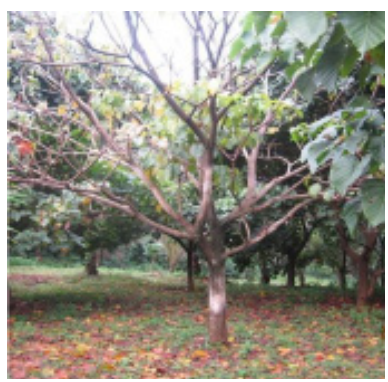

a

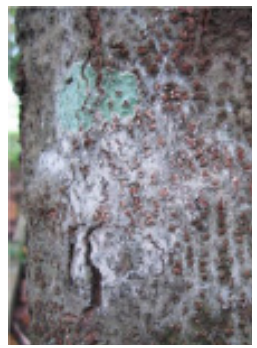

d

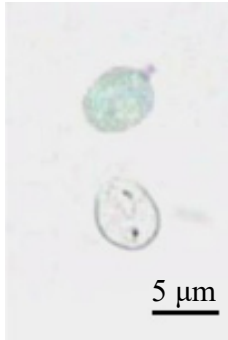

$\mathrm{g}$

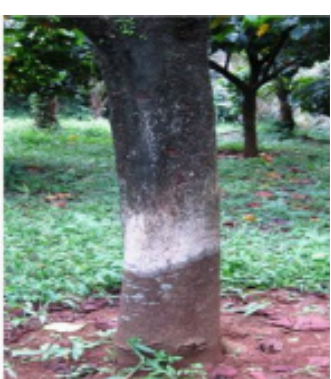

b

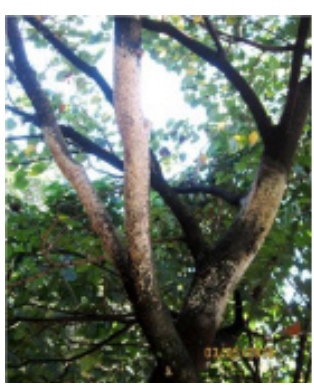

c

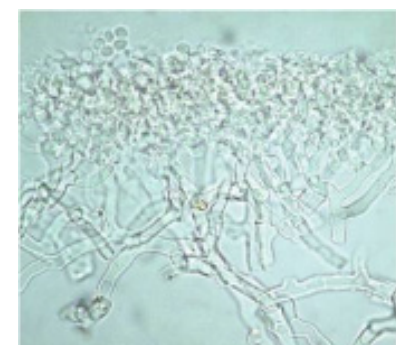

e

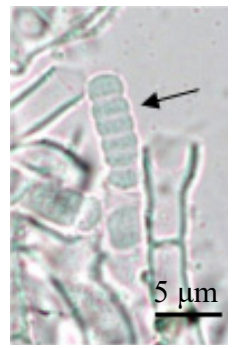

$\mathrm{h}$

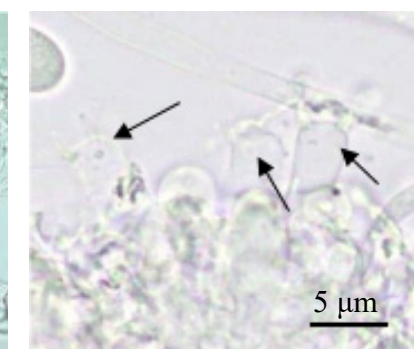

f

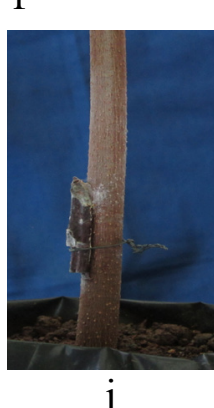

Gambar 1. Erythricium salmonicolor pada tanaman kemiri sunan. a, Gejala dan tanda tanaman terserang; b, Koloni pada batang; c, Koloni pada cabang; d, Miselium yang membentuk titiktitik warna terang (pustule); e, Hymenium; f, Basidium $(\rightarrow$ ); g, Basidiospora; h, Konidium $(\rightarrow)$; i, Koloni (EK-01) pada medium ADK; dan j, Miselium tumbuh pada permukaan batang saat inokulasi buatan.

\section{Pertumbuhan E. salmonicolor pada Perlakuan Suhu, Cahaya dan Fungisida}

Miselium tumbuh pada kisaran suhu 25-34 ${ }^{\circ} \mathrm{C}$. Suhu $28{ }^{\circ} \mathrm{C}$ merupakan suhu optimum bagi pertumbuhan miselium $E$. salmonicolor (Gambar 2). Cendawan yang tumbuh pada suhu $25{ }^{\circ} \mathrm{C}$ dan $28{ }^{\circ} \mathrm{C}$ tumbuh tebal seperti kapas, tetapi tidak menghasilkan basidium maupun konidium pada 21 hari setelah inokulasi.

Pemberian cahaya tidak menyebabkan koloni E. salmonicolor tumbuh lebih cepat dan lebih subur dibandingkan pada kondisi gelap (Gambar 3a dan 3b). Koloni yang diberi perlakuan cahaya menghasilkan warna koloni yang lebih terang dibandingkan yang tidak terpapar cahaya.
Kedua fungisida yang diuji (mankozeb dan tembaga hidroksida) efektif menekan E. salmonicolor. Mankozeb menekan pertumbuhan koloni E. salmonicolor lebih tinggi dibandingkan dengan tembaga hidroksida (Gambar 4). Konsentrasi mankozeb 100 ppm lebih efektif menekan pertumbuhan koloni E. salmonicolor dibandingkan dengan 500 ppm tembaga hidroksida.

Analisa regresi menunjukkan perbedaan yang nyata pada setiap kenaikan konsentrasi 100 ppm tembaga hidroksida terhadap daya hambat pertumbuhan E. salmonicolor. Sebaliknya, mankozeb tidak menunjukkan perbedaan yang nyata diantara konsentrasi yang diuji pada E. salmonicolor (Gambar 5). Uji homogenitas pada kedua persamaan 


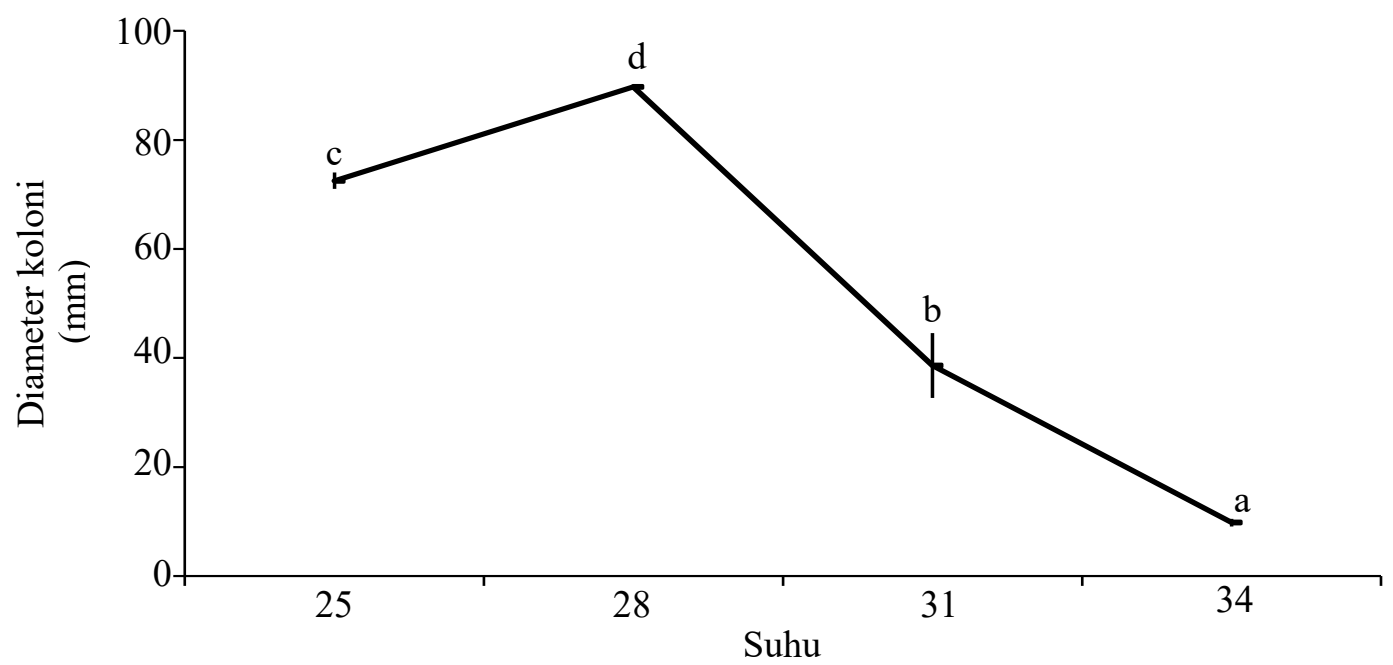

$\left({ }^{\circ} \mathrm{C}\right)$

Gambar 2 Diameter koloni EK-01 pada medium agar-agar dekstrosa kentang 5 hari setelah inkubasi pada beberapa suhu. Huruf yang sama di atas kategori suhu tidak berbeda nyata menurut uji Duncan pada taraf 5\%. Garis vertikal menunjukkan standar deviasi.

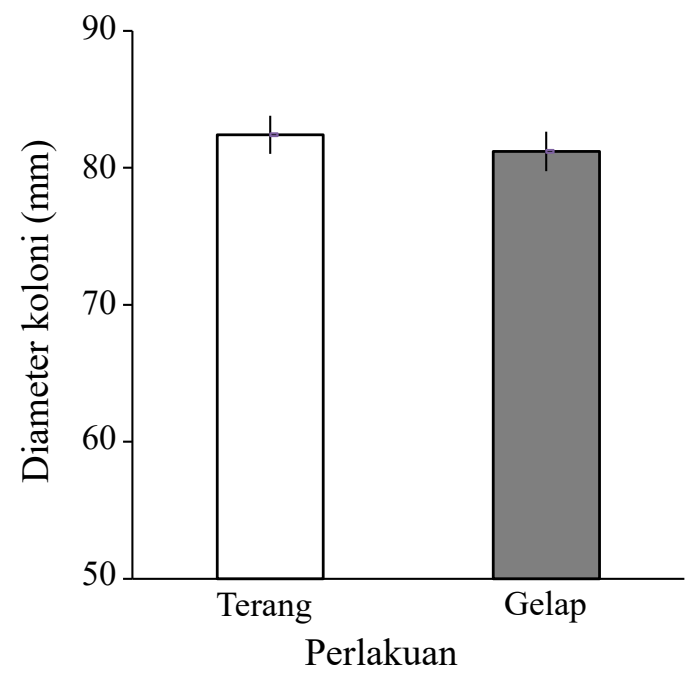

a

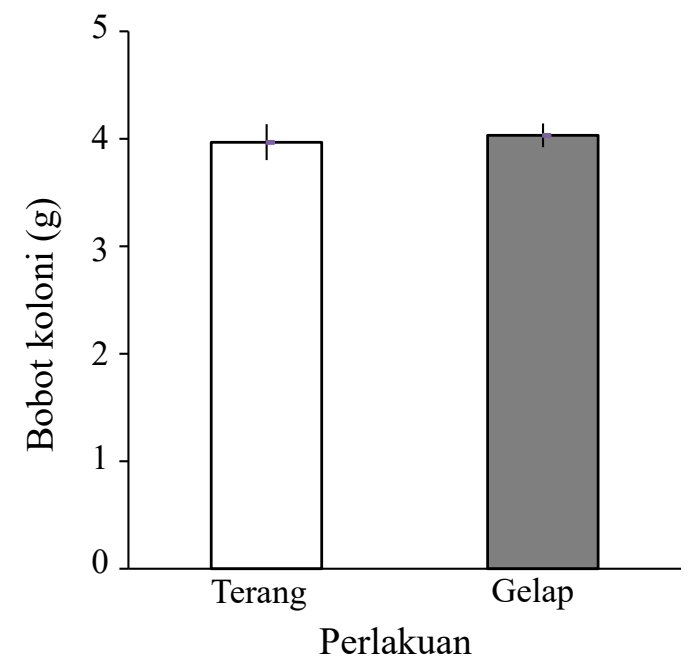

b

Gambar 3 Diameter dan bobot koloni EK-01 yang tumbuh pada medium agar-agar dekstrosa kentang pada keadaan terang dan gelap. a, 5 HSI; dan b, 15 HSI.

fungisida tembaga hidroksida dan mankozeb memberikan pengaruh yang berbeda terhadap penekanan pertumbuhan E. salmonicolor, mankozeb lebih efektif menekan pertumbuhan koloni E. salmonicolor.

\section{PEMBAHASAN}

E. salmonicolor dilaporkan menyerang akasia, jeruk, karet, kopi, kakao, dan teh (Old et al. 2003). Di Indonesia terdapat 102 genus tanaman yang menjadi inang E. salmonicolor, tetapi kemiri sunan tidak dilaporkan sehingga penelitian ini merupakan laporan pertama $E$. salmonicolor pada tanaman kemiri sunan di Indonesia. Serangan E. salmonicolor tidak segera mematikan tanaman inang karena proses perkembangan berlangsung lambat dan memerlukan kondisi lingkungan yang mendukung.

Basidium berbentuk gada, dengan 4 sterigmata dan koloni berwarna putih sampai oranye merupakan ciri morfologi dari $E$. salmonicolor (syn. Corticium salmonicolor) (Jülich 1975). Cendawan E. salmonicolor mempunyai 4 tahap pertumbuhan: koloni 


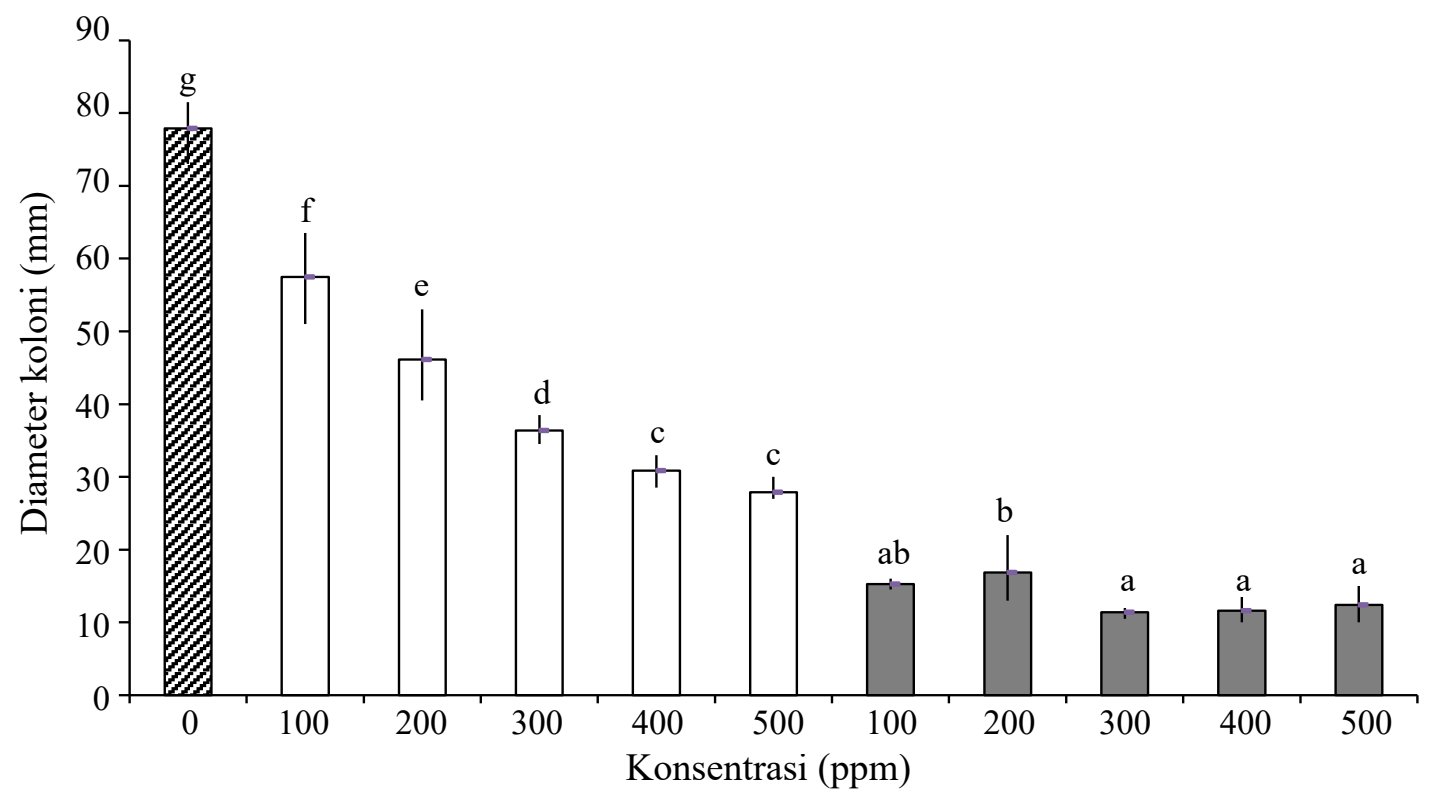

Gambar 4 Diameter koloni EK-01 yang tumbuh pada medium agar-agar dekstrosa kentang yang sudah diberi perlakuan fungisida dan diinkubasi selama 5 hari. Huruf yang sama pada tiap grafik batang tidak berbeda nyata menurut uji Duncan pada taraf 5\%. $\mathbb{Z}$, Kontrol; , Fungisida mankozeb; dan $\square$, Tembaga hidroksida pada konsentrasi 100-500 ppm.

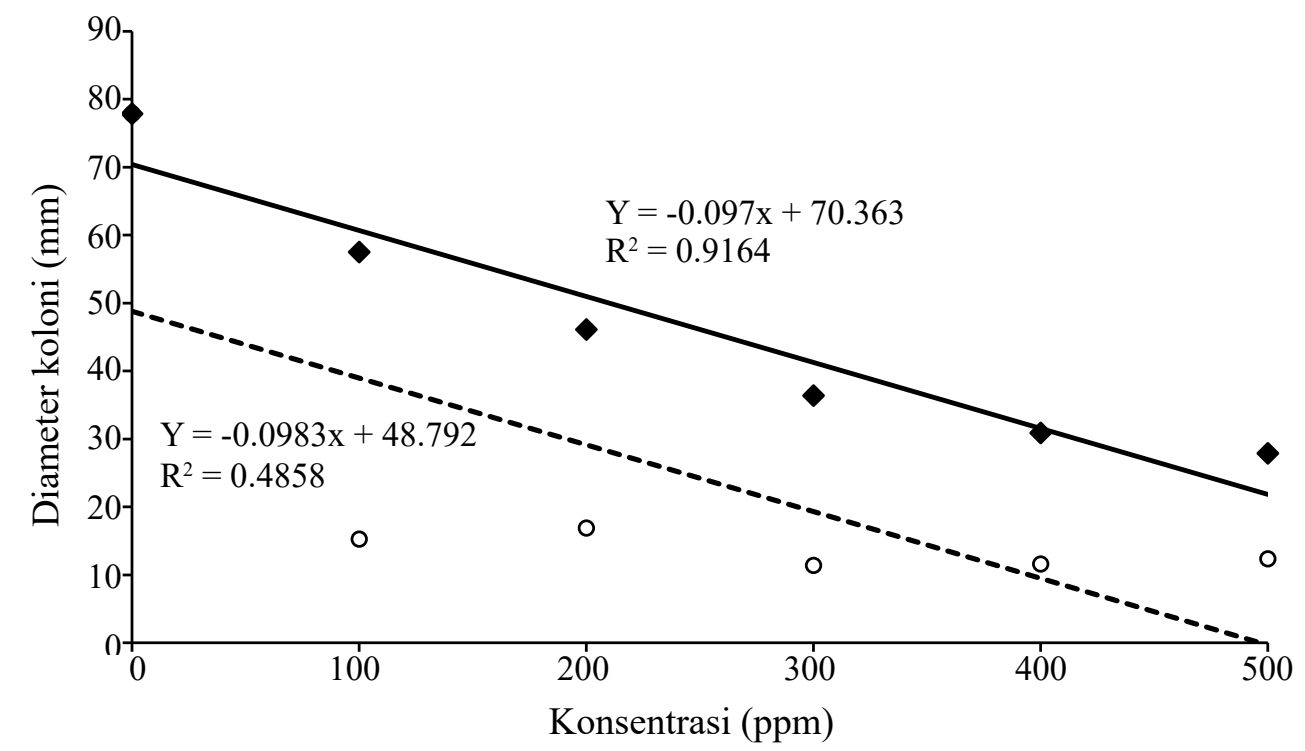

Gambar 5 Kepekaan Erythricium salmonicolor pada jenis dan konsentrasi fungisida. $\bigcirc$, Mankozeb; dan $\bullet$, Tembaga hidroksida.

tumbuh cepat dan tipis menyerupai sarang laba-laba, fase infeksi ditandai adanya miselium yang mengumpul, tebal dan sporadis (pustule), terjadinya kerak atau pecah pada kulit batang terinfeksi (pink incrustation), dan fase pembentukan konidium (necator) (Old et al. 2003).

Cendawan E. salmonicolor (EK-01) mempunyai suhu pertumbuhan optimum $28{ }^{\circ} \mathrm{C}$. Hal serupa juga dilaporkan oleh
Shamsuri et al. (1997) pada tanaman karet, sedangkan kisaran suhu untuk pertumbuhan ialah 5-40 ${ }^{\circ} \mathrm{C}$. Di Jepang, miselium $E$. salmonicolor pada sembilan inang yang berbeda menunjukkan pola pertumbuhan yang sama, yaitu tumbuh optimum pada $25{ }^{\circ} \mathrm{C}$, lebih rendah dibandingkan dengan $E$. salmonicolor yang tumbuh di daerah tropis (Nomi dan Kobayashi 2000). 
Cahaya dengan intensitas 400 luks tidak berpengaruh nyata terhadap pertumbuhan dan bobot koloni E. salmonicolor. Di awal pengamatan lapangan, koloni E. salmonicolor tumbuh lebih panjang dengan warna lebih terang pada sisi timur batang primer kemiri sunan. Kondisi lingkungan yang lembap dan curah hujan tinggi pada bulan Maret, serta kanopi tanaman yang lebat tidak menyebabkan terjadinya kenaikan suhu yang tinggi pada permukaan batang primer yang terserang. Sebaliknya pada musim kemarau, koloni E. salmonicolor pada ranting di bagian atas, cenderung tumbuh di bagian bawah ranting yang terlindung dari sinar matahari. Hal ini mengindikasikan, pengaruh cahaya lebih besar pada kenaikan suhu medium sehingga menghambat pertumbuhan koloni, dibandingkan dengan pengaruhnya secara langsung pada cendawan. Alam et al. (2001) berpendapat bahwa perlakuan cahaya tidak berpengaruh nyata terhadap kecepatan tumbuh koloni tetapi berpengaruh terhadap daya sporulasi Botryodiplodia theobromae. Respons Cerrena unicolor, Pycnoposrus sanguineus dan Phlebialindtneri (Polyporales) untuk menghasilkan enzim-enzim pendegradasi kayu, tidak sama terhadap panjang gelombang cahaya yang diberikan. C. unicolor dan $P$. sanguineus membutuhkan warna biru untuk meningkatkan sintesis enzim lakase, tetapi $P$ lindtneri membutuhkan warna hijau (Janusz et al. 2016).

Fungisida berbahan aktif tembaga hidroksida dan mankozeb banyak digunakan untuk mengendalikan penyakit tanaman yang disebabkan oleh cendawan. Perbedaan bahan aktif fungisida menyebabkan mankozeb lebih efektif menekan pertumbuhan $E$. salmonicolor dibandingkan dengan tembaga hidroksida. Pada konsentrasi $1000 \mathrm{ppm}$, fungisida mankozeb lebih efektif daripada fungisida berbahan aktif tembaga dalam melindungi tanaman buahbuahan dari Erwinia amylovora, Pseudomonas syringae dan Agrobacterium tumefaciens di rumah kaca (Mikicinski et al. 2012).

Tembaga hidroksida relatif tidak berbahaya untuk agens hayati (2500 ppm untuk Trichoderma) sehingga dalam penggunaannya di lapangan dapat dikombinasikan (Valarmathi et al. 2013). Ion tembaga merupakan racun kontak, mempunyai afinitas pada berbagai kelompok senyawa protein dan enzim (Okorski et al. 2015). Fungisida tembaga efektif mengendalikan E. salmonicolor pada pohon karet dan efektifitasnya meningkat dalam ukuran nano (Cao et al. 2014).

Mankozeb merupakan racun kontak yang menghambat perkecambahan spora berbagai kelas cendawan (Gullino et al. 2010) dan efektif sebagai protektan atau sebelum terjadi infeksi (Wong dan Wilcox 2001). Setelah terjadi kontak dengan air, mankozeb melepas ethylen bisisothiocyanate sulfidae (EBIS), terurai lagi menjadi ethylen bisisothiocyanate (EBI) yang beracun dan merusak sistem enzim di dalam sitoplasma dan mitokondria sel cendawan (Gullino et al. 2010).

Cendawan E. salmonicolor umum ditemukan di area bercurah hujan tinggi, tersebar melalui basidiospora maupun konidium dan menginfeksi jaringan kulit tanaman (Lee 2003). Musim hujan yang panjang di Bogor pada tahun ini menciptakan kondisi ideal bagi E. salmonicolor untuk berkembang. Tindakan budi daya berupa pemangkasan, sanitasi, dan pengaturan jarak tanam kemiri sunan serta aplikasi fungisida apabila diperlukan berguna dalam menekan serangan E. salmonicolor.

\section{DAFTAR PUSTAKA}

Alam MS, Begum MF, Sarkar MA, Islam MR, Alam MS. 2001. Effect of temperature, light and media on growth, sporulation, formation of pigments and pycnidia of Botryodiplodia theobromae Pat. Pakistan J Biol Sci. 4(10):1224-1227. DOI: https:// doi.org/10.3923/pjbs.2001.1224.1227.

Aguilar NO, Oyen LPA. 2002. Reutealis trisperma (Blanco). Di dalam: Van der Vossen HAM, Umali BE, editor. Plant Resources of South-East Asia No. 14. Vegetable Oils and Fats. Bogor (ID): Prosea Bogor Indonesia. hlm 112-115.

Akrofi AY, Attal A, Assuah M, Kumi-Asare E. 2014. Pink disease caused by Erythricium 
salmonicolor (Berk \& Broome) Burdsall: an epidemiological assessment of its potential effect on cocoa production in Ghana. J Plant Pathol Microb. 5:215220 DOI: https://doi.org/10.4172/21577471.1000215

Cao VD, Nguyen PP, Khuong VQ, Nguyen CK, Nguyen XC, Dang CH, Tran NQ. 2014. Ultrafine copper nanoparticles exhibiting a powerful antifungal/killing activity against Corticium salmonicolor. Bull Korean Chem Soc. 35(9):2645-2648. DOI: https:// doi.org/10.5012/bkcs.2014.35.9.2645.

Griffin JM, Lovett GM, Arthur MA, Weathers KC. 2003. The distribution and severity of beech bark disease in the Catskill Mountains, NY. Can J Forest Res. 33:17541760. DOI: https://doi.org/10.1139/x03093.

Gullino ML, Tinivella F, Garibaldi A, Kemmit GM, Bacci L, Sheppard B. 2010. Mancozeb past, present and future. Plant Dis. 94(9):1076-1087. DOI: https://doi. org/10.1094/PDIS-94-9-1076.

Janusz G, Sulej J, Jaszek M, Jaroszuk MO. 2016. Effect of different wavelengths of light on laccase, cellobiose dehydrogenase, and proteases produced by Cerrena unicolor, Pycnoporus sanguineus and Phlebia lindtneri. Acta Biochimica Polinica. 63(2):22-228. DOI: 10.18388/ abp.2015_1235. DOI: https://doi. org/10.18388/abp.2015_1235.

Jülich W. 1975. Studies in resupinate Basidiomycetes-III. Persoonia. 8(3):291305.

Lee S. 2003. Pathology of tropical hardwood plantations in South-East Asia. New Zealand J Forestry Sci. 33(3):321-335.

Mikicinski A, Sobiczewski P, Berczynski S. 2012. Efficacy of fungicides and essential oils against bacterial disease of fruit trees. J Plant Protec Res. 52(4):467-471. DOI: https://doi.org/10.2478/v10045-0120075-7.

Nomi CS, H Kobayashi, T. 2000. Occurence and life-history of pink disease caused by Erythricium salmonicolor in Northern Kanto, Honshu, Japan. J Agric Sci Tokyo Nogyo Daigaku. 44(4):252-262.

Old KM, Wingfield MJ, Yuan ZQ. 2003. A Manual of Diseases of Eucalypts in SouthEast Asia. Bogor (ID): ACIAR CIFOR.

Okorski A, Pszczolkowska A, Oszaco T, Nowakowska JA. 2015. Current possibilities and prospects of using fungicides in forestry. Forest Res Papers. 76(2):191-206. DOI: https://doi. org/10.1515/frp-2015-0019.

Roux J, Coetzee MPA. 2005. First report of pink disease on native trees in South Africa and phylogenetic placement of Erythricium salmonicolor in the homobasidiomycetes. Plant Dis. 89(11):1158-1163. DOI: https:// doi.org/10.1094/pd-89-1158.

Shamsuri MH, Omar M, Napi D. 1997. Studies on epidemiology of pink disease and the effect of temperature on mycelial growth of Corticium salmonicolor of Hevea rubber. J Nat Rubb Res. 12(1):58-66.

ValarmathiP,KumarPS, VanarajP,Ramalingam R, Gopal C. 2013. Compatibility of copper hydroxide (Kocide 3000) with biocontrol agents. IOSR-JAVS. 3(6):28-31. DOI: https://doi.org/10.9790/2380-0362831.

Wong FP, Wilcox WF. 2001. Comparative physical modes of action of azoxystrobin, mancozeb, and metalaxyl against Plasmopora viticola (grapevine downey mildew). Plant Dis. 85(6):649656. DOI: https://doi.org/10.1094/ PDIS.2001.85.6.649. 